\title{
ANÁLISE DE DESEMPENHO DE UM MOTOR DE COMBUSTÃO INTERNA DO CICLO OTTO UTILIZANDO COMO FONTE ENERGÉTICA GASOLINA E UMA MISTURA GASOLINA - ETANOL
}

\author{
SILVIO EDUARDO TEIXEIRA PINTO DA SILVA ${ }^{1}$, ERIC CORRÊA ALONSO \\ SERPA $^{2}, \underline{\text { YGOR PEIXOTO RANGEL }}{ }^{2}$
}

(1) Pesquisador Orientador - Laboratório de Análise e Projeto de Sistemas Mecânicos - LAPSIM/ISECENSA - Curso de Engenharia Mecânica - Institutos Superiores de Ensino do CENSA - ISECENSA, Rua Salvador Correa, 139, Centro, Campos dos Goytacazes, RJ, Brasil ISECENSA; (2)Aluno voluntário de

Iniciação Cientifica do PROVIC/ISECENSA.

O motor é uma máquina térmica, pois converte a energia térmica resultante da combustão, em energia mecânica útil. Segundo dados da Organização Mundial da Indústria Automobilística, a frota mundial de veículos chegou a 1 bilhão de veículos. Somente no Brasil a frota já é próxima a 30 milhões de unidades. Diversos estudos vêm sendo realizados na busca de combustíveis mais eficientes e que reduzam a emissão de gases poluentes na atmosfera. O etanol (álcool etílico) vem sendo testado como combustível alternativo para a substituição do uso de alguns derivados do petróleo em motores de combustão interna. Diversos estudos comprovaram que a adição de álcool à gasolina aumentaria a potência desenvolvida no motor devido a sua característica antidetonante sem comprometer a sua vida útil, no entanto a adição do etanol precisa ser realizada em uma porcentagem adequada devido ao seu menor poder calorífico. Por este motivo, o presente trabalho comparou a influência da mistura gasolina e etanol no desempenho de motor de combustão interna do ciclo Otto. Para isto foi realizada a avaliação em um motor de combustão interna estacionário de 389 cilindradas e potência máxima de 13 HP. Foram utilizados dois combustíveis: uma gasolina sem a presença de etanol e a outra gasolina disponível no mercado com aproximadamente 27,5\%. Inicialmente foi obtida a taxa de compressão do motor. Em seguida foram realizados testes para determinar a potência efetiva, taxa de consumo de combustível, o torque, vazão mássica de ar admitida no cilindro e a relação ar combustível. Após a realização dos ensaios constatou-se que a potência efetiva da gasolina é superior à mistura (gasolina + etanol) para qualquer rotação, porém o consumo específico dos dois combustíveis foi similar indicando que a vantagem de elevada potência efetiva da gasolina é contrabalançada pelo maior consumo, demonstrando que os dois combustíveis apresentam performances semelhantes em determinadas faixas de rotação.

Palavras-chave: motores de combustão interna, ciclo otto, consumo.

Instituição de fomento: PROVIC/ISECENSA. 